\title{
Education, anthropology, ontologies'
}

Renzo Taddei"

Ana Laura Gamboggill'

I- Acknowledgments: Renzo Taddei was partially funded by the National Science Foundation (951516), the Inter-American Institute for Global Change Research (CRN 3035 and 3106), and the Comitas Institute for Anthropological Study. The authors dedicate this article to Lambros Comitas, whose dedication to education, anthropology, and ethnography is a perennial source of inspiration to us.

II- Universidade Federal de São Paulo, São Paulo, SP, Brasil.

Contact: renzo.taddei@unifesp.br

III- Centro Universitário SENAC. São

Paulo, SP, Brasil.

Contact: anagamboggi@gmail.com

\begin{abstract}
The goal of this paper is to analyze the relation between anthropology and education, and the relation of both with the experience of life, in a context of debates in which epistemological concerns have gradually been substituted by a reflection on the ontological dimension of existence. Starting with a discussion on the asymmetric historical relation between anthropology and education, in what concerns the analysis of sociocultural dimensions of learning, we propose the inversion of the terms of the expression anthropology of education, and then discuss the paradoxes that characterize the relation between the professional education of the anthropologist, identified as an epistemological exercise, and the ontological dimension of the ethnographic experience. From this discussion, the question of the body of the ethnographer emerges as something absent in mainstream ethnographic production, which is identified as an index of the presence of one of the structuring dichotomies of Western epistemology: the separation of mind and body. The works of authors associated to the so-called ontological turn in social sciences are brought to the discussion, and from the analysis of some of their main contributions, new points of contact between education and anthropology, on more symmetric grounds, emerge. Among these, it is of special interest the one that focuses on happiness and the plenitude of becomings, which, albeit unprecedented themes in anthropology, have been part of the educational debates of the last four decades.
\end{abstract}

\section{Keywords}

Ethnography - Anthropology - Ontology - Symmetry - Education. 


\section{Educação, antropologia, ontologias'}

Renzo Taddeil"

Ana Laura Gamboggill

\section{Resumo}

Este texto tem como objetivo analisar a relação entre a antropologia e a educação, bem como entre esses dois campos e a experiência da vida, num contexto de debates acadêmicos em que preocupações mais propriamente epistemológicas cedem gradativamente espaço à reflexão sobre a dimensão ontológica da existência. A partir de uma discussão da relação histórica assimétrica entre a antropologia e a educação na reflexão sobre as dimensões socioculturais do aprendizado, propomos a inversão dos termos da expressão antropologia da educação, e em seguida discutimos os paradoxos existentes na relação entre a educação profissional do antropólogo, enquanto exercício epistemológico, e a dimensão ontológica da vivência etnográfica. Emerge dai a questão do corpo do etnógrafo como elemento ausente na reflexão etnográfica, indício da presença de uma das dicotomias estruturantes da epistemologia ocidental, a divisão entre corpo e mente. Os trabalhos de autores ligados à chamada virada ontológica nas ciências sociais são então trazidos ao debate e, a partir da análise de algumas de suas contribuições centrais, vêm à tona novos pontos de contato entre os campos da educação e da antropologia, em bases mais simétricas. Dentre esses, destacam-se os temas da felicidade e da plenitude do devir, inéditos na antropologia, mas presentes nos debates pedagógicos das últimas quatro décadas.

I- Agradecimentos: Renzo Taddei foi financiado, em etapas distintas de sua pesquisa, pela National Science Foundation (951516), pelo Inter-American Institute for Global Change Research (CRN 3035 e 3106), e pelo Comitas Institute for Anthropological Study. Os autores dedicam este artigo a Lambros Comitas, cuja dedicação à educação, à antropologia e à etnografia é-nos fonte perene de inspiração.

II- Universidade Federal de São Paulo, São Paulo, SP, Brasil.

Contato: renzo.taddei@unifesp.br

III- Centro Universitário SENAC. São Paulo, SP, Brasil.

Contato: anagamboggi@gmail.com

\section{Palavras-chave}

Etnografia - Antropologia - Ontologia - Simetria - Educação. 


\section{Introduction: asymmetries}

This article addresses how education and anthropology relate to each other. The argument starts from a discussion of the tensions between the professional education of anthropologists and the existential dimensions of ethnographic work. The goal of this paper is to set both against the background of the life experience, in the context of academic debates in which epistemological preoccupations give room to debates on the ontological dimension(s) of existence. A key point of interest in our analysis is the relationship between the professional education of the anthropologist, as an epistemological exercise, and the ontological dimension of the ethnographic experience.

Our departure point is the fact that the relationship between anthropology and education, as academic fields, has been historically marked by an accentuated asymmetry. The expression anthropology of education itself illustrates this fact. In it, anthropology is evoked to clarify what education is, or at least what are its institutionalized practices, such as schooling, and what implications they have for collective life.

As a subdivision of the wider field of anthropology, anthropology of education has been in existence for many decades. In the United States, for instance, German-born Franz Boas founded the first department of anthropology of the Americas at Columbia University. Here research in the field of anthropology of education began in the 1930s in Teachers College, the graduate center of education and education-related disciplines. The name of the current graduate program at Columbia University is not anthropology of education but rather anthropology and education. Yet the asymmetry is still there, once the goal of its activities has been the use of anthropological approaches (sometimes uncritically) to reflect (critically) in regard to education and its practices, in the United States and abroad. There have been changes in that respect over the last decade, and they will be discussed further along this text. Still, it is a fact that the asymmetrical relationship has remained relatively stable for almost the entire past century.

\section{Anthropology $\leftrightarrows$ Education}

There are many possible strategies for disarticulating an asymmetric relationship. We will use as our main analytical strategy the conceptual implications of, literally, the simple inversion of terms. By inverting the terms of the expression anthropology of education, we get education of anthropology.

If we begin by analyzing both the universe of education and the field of anthropology, it is remarkable that any discussion about the education of anthropologists is absent, and the same is true for the role of anthropologists as educators. These are issues that appear only anecdotally in the literature, and mainly in historiographic works, such as those of George Stocking Jr., one of the most important historians of anthropology (see, e.g. STOCKING JR., 1982, 1992). Even there, education is taken as an unproblematic aspect of intellectual genealogies. Two of the best known examples may perhaps be the ways through which the notion of culture as part of the spirit of a people (Volksgeist), as an important feature of German Romanticism, reached the United States through Franz Boas. He exerted an enormous influence on the constitution of the so-called Culture and Personality School, in which Ruth Benedict and Margaret Mead, both students of Boas, played prominent roles (BUNZL, 1996). A second example is the form through which Max Weber's semiotics and Alfred Schutz's phenomenology reached one of the most read authors in the history of anthropology, Clifford Geertz, through the works of Talcott Parsons (AUSTIN, 1979).

In these examples, education is taken as a process of transmission, or transduction at best, in which the conceptual basis and methodological strategies reproduce and 
disseminate themselves, almost against the human existence of anthropologists. This view is much closer to what Paulo Freire called "banking education" (1987) that most anthropologists would care to admit. The difference lies in the fact that in this picture ethnography introduces an element that education, in the banking model, does not contemplate: ethnographic field realities impose themselves as a disorganizing element in the transmission of content, which results in the novel character of ethnographic research. In any case, it is a noteworthy fact that theoretical and methodological paradigms remained stable for decades, in spite of the radical novelty brought about by the field experience. For instance, functionalism is alive and well, if not in anthropology, at least in a great amount of contemporary Western social science research.

The movement of self-critique that has marked American and European anthropologies since the mid-1970s, and especially in the 1980s, was responsible for bringing the issue of reflexivity onto the anthropological agenda. It remained almost exclusively circumscribed to the question of anthropological writing, in the matter of the authority of who writes and to the political implications of how anthropologists establish relations with their informants while in the field. The book Writing Culture, published in 1986 and organized by James Clifford and George Marcus, was an important benchmark in that context. The questions that they presented nevertheless remained focused on the political implications of the epistemological practices of the anthropologist, that is, to the conditions in which it was possible to produce knowledge about the social existence of the other, and the effects that these forms of knowledge production had on the social existence of such other.

Curiously, the implications of this critical movement on the ways in which anthropologists were educated did not surface. Instead, the impacts of that moment of self-criticism resulted in a transformation of the intellectual exercises to which students were subjected in their initial years of graduate school. They began reading and discussing the authors, then called postmodern, in addition to some post-structuralist philosophers, sometimes to exhaustion, but the probability that these intellectual exercises effectively transformed real-life experiences remained small.

In what concerns the role of the ethnographic experience in anthropology, it is notable that an abundance of discussions, since Malinowski (1978 [1922]), consider its importance in the process of construction on knowledge in general, and anthropological theories in particular. At the same time, and contradictorily, an analytical debate of its importance in the education of the researcher is absent. Generally, in Europe and the United States, the idea that the field experience is a fundamental rite of passage that defines the identity of the anthropologist survives in the anthropological realm. It is tacitly assumed that only from this moment on is it effectively possible to produce anything of anthropological quality. Therefore, the anthropologist is only capable of being creative in the presence of radical alterity. While among his or her peers, she arms herself with ideas and theories, and while among different people, she needs to have novel ideas. This perspective is almost always implicitly assumed, even if an anthropologist who dedicates some time to think about it can easily identify its inconsistencies.

In addition, there is the fact that in the absolute majority of graduate courses in the United States, Europe, and Latin America, courses exclusively dedicated to field methods are nonexistent. Instead, the reading of classic ethnographic monographs is privileged, and the student is expected to mimic them, critically or uncritically, when in the field. It is not strange then that field research presents itself as a source of anxiety to anthropology students, and many feel that they are pushed into the field without much preparation for what they might encounter. As undergraduate students, they may never go through a field experience, 
and activities are restricted to theoretical discussions. Programs of "scientific initiation" have changed this panorama in Brazil, and yet it is not uncommon to find in the best undergraduate programs in anthropology (or in social sciences with a major in anthropology), students who graduate without having any field experience. No one expects much from them, beyond being able to discuss the classics, ancient and contemporary, and that they attend graduate school.

\section{The (absent) body of the ethnographer}

There is one ironic element in this panorama: the fact that ethnography is, in itself, an experience founded in the idea that the researcher should learn the ways of life being studied. In other words, the idea of learning exists as a structuring element of ethnography. Yet, the forms of learning implicated in the ethnographic experience are generally very different from the educative processes that students are exposed to in the initial years of their anthropological education.

In the field, the anthropologist learns about the ways of living of the group under study by trying to live in its social context. For that, he or she initially needs to solve the basic issues of existence, such as how to get relief from physiological needs, guarantee physical integrity, eat, and sleep. All of that is in a situation of cultural shock, by being among people who do things differently, things that are both interesting and unpredictable. The researcher commonly experiences an inexorable sensation of asynchrony and lack of compass with the new world in which she finds herself. These issues raise intense emotional reactions, often including anxiety and fear. The researcher, sometimes in desperation, dedicates a good amount of time to her body and the management of her emotions. In a certain way, these questions of corporeal existence remain present throughout the ethnographic research, and the theoretical insights the researcher may have will take place in such a context. As time, effort, and dedication are invested in the research, anxiety and fear become less perceptible, and the researcher increases the synchronization of her rhythms with those of the groups in which she is immersed.

It is remarkable how Malinowski explicitly mentions, in the famous methodological chapter in Argonauts of the Western Pacific, the need for learning the native ways of life. However, in terms of coexistence in the deeper sense of existential communion, Malinowski limits himself to only mentioning learning the language of the natives. For everything else, the term learning is equivalent to collecting information regarding the studied phenomena. In this case, the more fundamental existential questions of his experiences in the field remained unknown and unedited until the controversial posthumous publication of his field diaries (MALINOWSKI, 1997).

When the researcher returns to her original institutional context to finally produce the master's thesis or the doctoral dissertation, she is compelled to produce a text that imitates the classics, works in which the focus of discussion is set on epistemological issues: how did her interlocutors think and articulate their discourses, what did they do with them, and how did the anthropologist's and native's discourses interact with each other. The researcher, who has spent a great amount of time synchronizing her viscera, bodily and emotional rhythms (TADDEI, 2014a), and the exchange of substances and affects (TADDEI, 2014b), with those of her local interlocutors, now needs to abstract all of that and produce a work focused on the concepts and ideas through which the "culture and society of the natives" manifest themselves. In summary, she needs to extract from her visceral field experience all that cannot be reduced to fit the concepts and ideas that mark the paradigmatic genres of ethnographic writing. 
Dramatic as it may seem, there is another side to this matter. Since the majority of students are not trained to perceive the subjective amplitude of experience when in an analytical mode of thinking, few people would know how to give textual form to existentially rich field experiences. As a result of being caught in this scission between existence and mainstream genres of writing, anthropologists become, anecdotally, weird people who write incredible books.

Perhaps this is the reason why ethnography is considered to be a "rite of passage" (WENGLE, 2005, p. 6) in American and European anthropological traditions. The rite of passage, in its classic anthropological formulation, constitutes a dramatic moment of social and personal change, often materialized in and through the bodies of the individuals involved, and its efficacy does not reside in its explanatory power, quite the contrary (VAN GENNEP 2010 [1909]; TURNER, 1995 [1966]). What we are proposing here is that mainstream anthropological traditions are not capable of openly discussing the most profound existential dimensions of ethnography because Western forms of academic thinking focus so resolutely in approaches that are descriptive, textual, denotative, and logocentric. The cost of that is to stifle students expressive strategies mediated by other structures or configurations, such as emotional and corporeal. Bodies and emotions have been topics of interest in anthropology when applied to the ethnographed subjects, not of the anthropologist. The expression ethnographic refusal as proposed by Sherry Ortner (1995) to account for resistance to the "thickness" of the field experience (an allusion to Geertz's thick description; see GEETRZ, 1977 [1972]) applies well here.

One way through which critical analyses of this problem appeared, in the anthropological production of the end of the 20th century, was the idea that for a series of reasons-conceptual, perceptual, and even psychoanalytic-, the anthropologist becomes interested in the life of the interlocutor but is not capable of effectively connecting with it and ends up talking about herself, her culture, and emotions, even if indirectly. A particularly well-known example of this is the controversy surrounding Margaret Mead's Coming of Age in Samoa (2001 [1928]), in which she is accused, by Derek Freeman and others, of fantasizing about the sexual lives of Samoan adolescents as a reflex of her own desire for sexual freedom in American society (FREEMAN, 1983). Geertz called it ethnographic ventriloquism (1988). Roy Wagner develops this question brilliantly in his book The Invention of Culture (2010 [1975]), in which he proposes that we speak about us through the other because we cannot speak about ourselves openly, or because it is exactly in the confrontation with the other that we constitute ourselves.

\section{Toward a post-asymmetric (therefore symmetric) approach}

The panorama delineated up to this point in the article is overly simplified; a more systematic and less linear approach to the problem would require more space. Our intent, nevertheless, was to select specific elements to contrast them with theoretical novelties that have gained visibility in recent years.

This new scenario is constituted by ideas that, although in themselves are not necessarily new, have been gaining salience in what has been produced by some anthropologists and authors from related disciplines. The intention is to disarticulate the asymmetry mentioned in the beginning of this article that is, naturally, not restricted to the relationship between anthropology and education (see, for instance, CORDEIRO, 2006; TRADIF, 2002) but is a founding aspect of the relationship between Western thinking and diverse forms of being in the world, especially those considered to be non-Western.

Contributions in this direction come from diverse intellectual and political fields, and we will be able to mention just a few of 
them here. Beyond anthropology, they include the social studies of science and technology, cultural studies, geography, environmental studies, philosophy, communication, feminism, veganism, and the social movement of anarchistic inspiration (such as 0ccupy Wall Street or the many Arab Springs).

In general, and despite the heterogeneity of the works mentioned below, there is a conceptual corpus that can be identified as containing the main formulations of this new approach. First, there is the effort to disassemble the fundamental dichotomies of Western thinking, such as nature vs. culture and mind vs. body. To Bruno Latour, one of the leading authors in the movement, modernity is not characterized by the development of forms of control of society over nature but rather by the conceptual separation between society and nature and the effects from such a way of understanding things (LATOUR, 1994).

There is also criticism toward liberal and individualistic perspectives in the way through which thinking about reality was constituted historically, and in the practices of scientific knowledge, as forms of access to such reality. What results is a global discussion about the social existence of science as a form of epistemological colonialism and on schooling as a civilizatory tool, as depicted in the film Schooling the World (2010). Not only is individualism strongly attacked, but also the idea of identity, and culture as a collective identity, are questioned. Many contributions in this area come from ethnographic works, especially those carried out in Melanesia and in Amazonia. Marilyn Strathern and Roy Wagner propose, from their research in Papua New Guinea, a revision of the individual concept as an indivisible social unit. Strathern (2006) mentions the concept of dividual as part of how her interlocutors understand subjects in the world, and Roy Wagner used the metaphor holography to refer to the same phenomenon (2001). Bruno Latour's analysis of Western science criticizes the idea of cultural relativism (and of multiculturalism), due to how it implies a uni-naturalism (i.e., the existence of a transcendent Nature, with capital N). He argues that this position necessarily depicts Western science as superior to all other forms of knowledge about reality (LATOUR, 1994, 2013). Eduardo Viveiros de Castro uses Latour's criticism in his analysis of Amerindian thought, proposing that in it one finds a multinaturalism instead: as part of what he and Tania Stolze Lima called Amerindian perspectivism, native Amazonians see a common humanity in living creatures. These creatures are, nevertheless, different in their nature or in the world in which they live, in the sense that each species has a distinctive existence and implies a unique point of view. The point of view is not taken here as an epistemological element in the existence of beings but rather as an ontological dimension. The interest of Viveiros de Castro and his colleagues lies not in understanding what Amerindians thought about the world, but rather what kinds of worlds are made possible by such points of view (VIVEIROS DE CASTRO, 2002).

Still, in the domain of the rupture of asymmetric dichotomies, some authors and works critical of individualism and the concept of identity in social sciences and humanities started to be identified as part of the post-identitarian and post-human movements. Judith Butler, for instance, one of the most important authors in the social and philosophical analysis of gender and sexuality, radically attacks the background heterosexuality in Western thought, the same that produces gender divisions and the correlations between masculine/social and feminine/natural (BUTLER, 1990). Here, we once again see a manifestation of the refusal to divide nature and society, a division that postulates that sexual orientation is rooted in biology while gender construction is a strictly cultural process (see also ORTNER, 1972). Butler affirms that libertarian feminism cannot be based on the concept of feminine once it is a product of background heterosexuality that sustains masculine domination. The construction of a free world should transcend sexual and gender 
identities. Identity, as a concept, is part of the problem, not of the solution.

The relationships between human beings and other living beings are equally problematic. Some authors, in particular Donna Haraway (1991) and Tim Ingold (1995), propose that human exceptionalism, that is, the understanding of human existence as an inexplicable singularity among the living organisms on the planet, is no more than a result of how European humanist thinking was historically constituted: not for what humans have, but for what animals supposedly do not have-consciousness, ability for analytic rationality, and so on. Animality is crafted as a condition for the idea of humanity and in opposition to it. In the development of this criticism, such authors, in conversation with others from disciplines including primatology and zoology, demonstrate how animals, such as dogs and monkeys, are capable of creating complex solutions to the problems they face, sometimes including human beings as resources. Haraway (2003) argues that the historical relationship between humans and dogs may be understood as the latter having made use of humans to increase their chances of survival.

Haraway's approach is often ironic, and that is more than mere personal style. According to her, one of the most serious limitations of Western scientific thinking is the need for totalization, for coherence, and for conceptual closure, while the experience of life is marked by partiality, incoherence, and the need to use incompatible things to solve practical problems. Haraway (1991) states that the ironic approach is what allows one to make productive use of incoherent things, as an epistemological and political strategy.

Authors such as Bruno Latour and Tim Ingold extend the criticism of human exceptionalism to include nonhumans that are notliving beings, butthings and objects (LATOUR, 2005; INGOLD, 2011). Latour (2005) proposes that the study of sociotechnical networks, in which humans and objects participate and affect each other mutually, replace approaches founded in aprioristic concepts that do not have empirical ballast, such as society. We should not explain phenomena using the idea of society; instead, societies (and collectivities, groups) are what are to be explained, by analyzing how humans and things associate with each other, that is, compounding networks. Haraway (1991) introduces the concept of cyborg as a metaphor for thinking in the human condition in the present time. The idea of the cyborg disarticulates the nature vs. society opposition, here materialized through the ideas of body/ natural and technology/social, and also in the notion of the body as an organic totality with a natural essence, against which difference is constructed as incompleteness. Haraway says that we are all cyborgs; this is an emancipatory notion in itself. Additionally, resistance against techno-capitalistic forms of oppression cannot take place through the evocation of a transcendent notion of nature, but instead through the subversive use of technology itself, of which our existence is indissociable. Cyborgs do not see any sense in the clash between technophobia and technophilia.

A last element should be added to this conceptual overview: criticism against the hyper valuation of cognitive and analytic dimensions in the human existence, to the detriment of other experiences of life and the world. Again, there are many authors with important contributions in this area. Tim Ingold, nevertheless, deserves special credit for the relevance of his theoretical contributions to debates about the learning process. Ingold supports the idea that knowledge is not something that can be transmitted (2000), once that would imply a stable world as a condition for the instability of the human agent (who transform themselves through learning). Instead, human and nonhuman agents are constituted and constitute the world through their actions and in deeply interconnected ways. Humans participate in a world in transformation, and develop in the world at the same time that the world, develops in them. This process takes 
place through the development of skills, of the capacity for creative improvisation along the lines of action and of life, as well as through forms of habitation. In a sense, the dynamic coexistence of humans and nonhumans are immersed in flows of energy and substance. The distinction between cognition and other human faculties makes little sense if the process of life is taken in its entirety: the engagement with and in the world, instead of the representation of the world, becomes the object of attention. Time and space stop being taken as given ontological dimensions and are understood as the results of complex relational processes (ESCOBAR, 2010, p. 98).

The implications of this critical movement are very radical; the concept of nature gives place to a multiplicity of socionatural worlds or natures-cultures. The focus of theoretical reflection goes from the conditions of thinking and the construction of truth to the comprehension of life forms and conditions for their existence. This choice for the ontological dimension, to the detriment of epistemological ones, has been called the ontological turn in social sciences. Life itself is understood as inseparable from the ways through which beings-living and nonliving-establish relationships among themselves. In summary, ontologies are seen as being fundamentally relational, reflecting the influence of the works by Deleuze and Guattari (1995) and Maturana and Varela (1995).

The fundamentally situated and contextualized character of the life experience implicates the recognition of the inevitable partiality of any form of knowledge. According to Haraway (1991), knowledge works in the world through strategic and ironic associations and is not based in universal generalizations. This theoretical standing puts the above-mentioned authors in close proximity with important social movements of the present. The concepts and practices of decentralized and distributed action, founded in the recognition of partiality and connectivity as conditions of existence, dissolve some of the frontiers that separate intellectual, academic production, and direct political action. In such an environment, disciplinary divisions such as history, geography, biology, anthropology, and politics make even less sense than they did in the past.

In general, there is a strong tendency in such a movement for the horizontalization of social thought. Authors such as Arturo Escobar (2010) refer to this question through the term plane ontologies, in opposition to the hierarchical, binary, structured, transcendent, and representational characteristics that mark the mainstream paradigms in social sciences. The idea of plane ontologies refers not only to horizontality but also to the dimensions of complexity, self-organization, and ontogenesis.

Consequently, scholars work toward the development of emergent forms of political action that are not based on essential identities linked to racial or gender issues. The idea that reality is a continuous constitution demands perennial ethnographic attention to such processes in a dynamic movement in which understanding the world, transforming the world, and transforming oneself in the world are indistinct (GRAEBER, 2009). These dimensions of relationality result in new politics of responsibilities, as a much larger than previously thought amount of human and nonhuman beings are part of the same network of complex relations. Actions inside the network must exist according to new paradigms of responsibility and responsiveness. Second, the forms of relation, degree of connectivity, and the ways in which this all connects to globalizing processes are necessarily variable. Once again, some authors suggest that this requires, in a broad sense, an ethnographic grounding for political action (ESCOBAR, 2010). Finally, this condition of relationality and connectivity implicates the need for considering the "absent other": the ones that are affected by my actions but are not here, being this other human, (non-human) animal, or thing (MASSEY, 2005, p. 189).

Escobar refers to this movement as a political ecology of difference. Its 
fundamental challenge considers what may be the main connection between the political and intellectual efforts of authors associated with the ontological turn and the field of education: what forms of being in the world we will have to create including educators, in an effort to materialize the ecologic and cultural sustainability of the world and of life? This fundamental question fuses education, anthropology, politics, sustainability, and the experiences of life and the world.

\section{Conclusion: felicity condition}

Social theories grounded in plane ontologies radically dislocate and question the separation between theoretical training and ethnographic practice in the production of knowledge about the other. In so doing, they challenge anthropology as it constituted itself throughout the 20th century and, consequently, the institutionalized forms of ethnographic education.

An important, if neglected, detail is the fact that the questioning brought about by the aforementioned authors reflects ideas initially developed by Paulo Freire and subsequently by the educators associated with ecopedagogy. This means that, despite the fact that the historical circumstances did not develop in this manner, the criticism toward anthropological education presented in this article could have developed in Brazil from inside ecopedagogy. Regardless, it seems that there is now an inedited favorable context for the alignment of education and anthropology, in the mutual and meaningful symmetrical collaboration.

In the face of current ecological crises, this collaboration becomes imperative. One reason resides in the saying that subjects should "search for happiness," - that is, construct the conditions for the plenitude of becoming; or, as the Brazilian poet Oswald de Andrade said in his "Anthropophagous Manifesto" (1976 [1928]), "happiness is the ultimate acid test" - is not part of anthropological traditions. In contrast, education incorporated the idea that happiness is a basic element in human existence and therefore should be a topic of educational debates more than 40 years ago. Now we need to articulate the work of being happy when speaking about the other (anthropology) and treat both as fundamental parts of how we (I and the other) exist in the world; of how we reconstruct ourselves in the world while transforming the world (ecopedagogy), or how we worldify ourselves.

\section{Referências}

ANDRADE, Oswald de. 0 manifesto antropófago. In: TELES, Gilberto Mendonça. Vanguarda européia e modernismo brasileiro: apresentação e crítica dos principais manifestos vanguardistas. 3. ed. Petrópolis: Vozes; Brasília, DF: INL, 1976.

AUSTIN, Diane. Symbols and culture: some philosophical assumptions in the work of Clifford Geertz. Social Analysis, n. 3, p. 4559, dec. 1979.

BUNZL, Matti. Franz Boas and the Humboldtian tradition: from Volksgeist and Nationalcharakter to an anthropological concept of culture. In: STOCKING JR., George Ward (Ed.). Volksgeist as method and ethic: essays on Boasian ethnography and the German anthropological tradition. Madison: University of Wisconsin Press, 1996. p. 17-78.

BUTLER, Judith. Gender trouble: feminism and the subversion of identity. New York: Routledge, 1990.

CLIFFORD, James; MARCUS, George. Writing culture: the poetics and politics of ethnography. Berkeley: University of California Press, 1986.

CORDEIRO, Telma Santa Clara. A aula universitária, espaço de múltiplas relações, interações, influências e referências: um ninho tecido com muitos fios. 2006. Tese (Doutorado em Educação) - Centro de Educação da Üniversidade Federal de Pernambuco, Recife, 2006. 
DELEUZE, Gilles; GUATTARI, Félix. Mil platôs: capitalismo e esquizofrenia. v. 1. São Paulo: 34, 1995.

ESCOBAR, Arturo. Postconstructivist political ecologies. In: REDCLIFT, Michael R.; WOODGATE, Graham (Eds.). The international handbook of environmental sociology. 2. ed. Cheltenham; Northampton: Edward Elgar, 2010. p. 91-105.

FREEMAN, Derek. Margaret Mead and Samoa: the making and unmaking of an anthropological myth. Cambridge: Harvard University Press, 1983.

FREIRE, Paulo. Pedagogia do oprimido. 17. ed. Rio de Janeiro: Paz e Terra, 1987.

GEERTZ, Clifford. The interpretation of cultures. New York: Basic Books, 1977.

GEERTZ, Clifford. Works and lives: the anthropologist as author. Cambridge: Polity Press, 1988.

GRAEBER, David. Direct action: an ethnography. Oakland: AK Press, 2009.

HARAWAY, Donna. A cyborg manifesto: science, technology, and socialist-feminism in the late twentieth century. In: HARAWAY, Donna. Simians, cyborgs and women: the reinvention of nature. New York: Routledge, 1991. p. 149-181.

HARAWAY, Donna. The companion species manifesto: dogs, people, and significant otherness. Chicago: Prickly Paradigm Press, 2003.

INGOLD, Tim. Being alive: essays on movement, knowledge and description. London: Routledge, 2011.

INGOLD, Tim. Humanidade e animalidade. Revista Brasileira de Ciências Sociais, São Paulo, v. 10, n. 28, p. 39-53, jun. 1995.

INGOLD, Tim. The perception of the environment. London: Routledge, 2000

LATOUR, Bruno. An inquiry into modes of existence: an anthropology of the moderns. Cambridge: Harvard University Press, 2013.

LATOUR, Bruno. Jamais fomos modernos: ensaio de antropologia simétrica. Rio de Janeiro: 34, 1994.

LATOUR, Bruno. Reassembling the social. Oxford: Oxford University Press, 2005.

MALINOWSKI, Bronislaw Kaspar. Os argonautas do pacífico ocidental. São Paulo: Abril, 1978.

MALINOWSKI, Bronislaw Kaspar. Um diário no sentido estrito do termo. Rio de Janeiro: Record, 1997.

MASSEY, Doreen. For space. Los Angeles: Sage, 2005.

MATURANA, Humberto; VARELA, Francisco. A árvore do conhecimento: as bases biológicas do conhecimento humano. Campinas: Psy, 1995.

MEAD, Margaret. Coming of age in Samoa. New York: William Morrow, 2001.

ORTNER, Sherry B. Is female to male as nature is to culture? Feminist Studies, v. 1, n. 2, p. 5-31, outono, 1972.

ORTNER, Sherry B. Resistance and the problem of ethnographic refusal. Comparative Studies in Society and History, v. 37, n. 1, p. 173-193, jan. 1995

SCHOOLING the world: the white man's last burden. Direção de Carol Black. USA; India: Lost People, 2010. 1 DVD-NTSC-R0, color, 66 min. Documentário.

STOCKING JR., George Ward. Race, culture, and evolution: essays in the history of anthropology. Chicago: University of Chicago Press, 1982.

STOCKING JR., George Ward. The ethnographer's magic: fieldwork in British anthropology, from Tylor to Malinowski. In: STOCKING JR., George Ward. The ethnographer's magic and other essays in the history of anthropology. Madison: University of Wisconsin Press, 1992. p. 12-59. 
STRATHERN, Marilyn. 0 gênero da dádiva: problemas com as mulheres e problemas com a sociedade na Melanésia. Campinas: Unicamp, 2006

TADDEI, Renzo. Devir torcedor. In: FERREIRA, Arthur Arruda Leal; MARTINS, André; SEGAL, Robert (Orgs.). Uma bola no pé e uma ideia na cabeça: 0 que o futebol nos faz pensar. Rio de Janeiro: UFRJ, 2014b.

TADDEl, Renzo. Ser-estar no sertão: capítulos da vida como filosofia visceral. Interface, Botucatu, v. 18, n. 50, p. 597-607, $2014 a$. Disponível em: <http://interface.org.br/wp-content/uploads/2015/02/interface-v.18-n.50.pdf. Acesso em: 2014>.

TARDIF, Maurice. Saberes docentes e formação profissional. Petrópolis: Vozes, 2002.

TURNER, Victor. The ritual process: structure and anti-structure. New York: Aldine Transaction, 1995.

VAN GENNEP, Arnold. The rites of passage. New York: Routledge Chapman \& Hal, 2010.

VIVEIROS DE CASTRO, Eduardo. Perspectivismo e multinaturalismo na América Indígena. In: VIVEIROS DE CASTRO, Eduardo. A inconstância da alma selvagem e outros ensaios de antropologia. São Paulo: Cosac Naify, 2002.

WAGNER, Roy. A invenção da cultura. São Paulo: Cosac Naify, 2010.

WAGNER, Roy. An anthropology of the subject. Berkeley: University of California Press, 2001.

WENGLE, John L. Ethnographers in the field: the psychology of research. Montgomery: University Alabama Press, 2005.

Received on April, 30, 2014

Approved on September, 23, 2014

Renzo Taddei is an assistant professor at the Federal University of São Paulo, where he teaches at the Sea Institute and the Graduate Program in Social Sciences. He received his doctoral degree from Columbia University, New York, in 2005.

Ana Laura Gamboggi is an assistant professor at the SENAC University Center and at the Graduate Program in Cultural Policy in the same institution. She received her doctoral degree from Universidad Autónoma Metropolitana-Iztapalapa, México City, in 2010. 